\title{
AKHLAK GURU PENDIDIKAN AGAMA ISLAM MENURUT AL-NAWAWI: \\ Studi kitab Al-Tibyan Fi Al-Adabi Hamalah Al-Qur'an
}

\section{Maliki* $^{*}$}

Abstrak: Masalah akhlak guru menjadi perioritas utama dan perhatian yang besar dikalangan ulama dari masa ke masa, termasuk imam al-Nawawi al-Dimasiqyi. Melalui kitab Al-Tibyan Fi Adabi Hamalah Al-Qur'an. Al-Nawawi memaparkan beberapa akhlak guru PAI yang perlu dimiliki guru.Akhlak Guru Pendidikan Agama Islam ialah sebagai berikut: Akhlak yang Mantap, Stabil dan Dewasa,Menurut al-Nawawi guru harus bersikap ikhlas hanya mencari keridhaan Allah dalam melaksanakan tugasnya, tidak mencintai pangkat dan kemewahan dunia, serta tidak memilki sifat dengki

Kata Kunci: Akhlak, Al-Tibyan Fi Adabi Hamalah Al-Qur'an.

\section{Pendahuluan}

A khlak adalah faktor terpenting bagi seorang guru agama untuk menentukan apakah ia menjadi pendidik dan 1 pembina yang baik bagi peserta didiknya, ataukah akan menjadi perusak bagi hari depan peserta didik yang masih kecil ( tingkat sekolah dasar) dan mereka yang sedang mengalami kegoncangan jiwa (tingkat menengah).

Di samping itu guru hendaknya meneladani jejak dan peranan para Nabi atau mengikutinya dalam pendidikan Islam. Sebagaimana di ketahui bahwa tujuan utamaNabi Muhammad SAW. Diutus adalah untuk memperbaiki dan menyempurnakan akhlak manusia. Karena itu beliau adalah orang yang memiliki keperibadian yang paling mulia. Beliau selalu menganjurkan kepada umatnya untuk berahlakul karimah kepada siapapun tanpa membedakan satu

* Penulis adalah Dosen Tetap IAI Nurul Hakim Kediri Lobar, e-mail: malicarabia12345@gmail.com 
dengan yang lain beliau juga menganjurkan supaya menjauhi sifatsifat yang buruk.

Masalah akhlak guru menjadi prioritas utama dan perhatian yang besar dikalangan ulama dari masa ke masa. Para ulama' Islam sesungguhnya mereka telah melakukan konsepsi terhadap akhlak guru, oleh karena mereka disamping sebagai ulama' sekaligus sebagai guru dan mahaguru (Hully Mukhtar, 2012: 91). Sehingga banyak diantara mereka seperti al-Ghazali, al-Kanani, al-Zamuji, Ibnu Khaldun dan lain-lain yang telah berusaha menyusun beberapa kompetensi personal/keperibadian yang perlu dimilki oleh guru. Demikian pula yang dilakukan oleh al-Imam al-Hafiz alFaqih al-Muhaddist Abu Zakaria bin Syaraf bin Mar'i bin Hasan bin Husein bin Muhamad bin Jum'ah bin Hasyam al-Nawawi alDimasqiy, atau lebih dikenal dengan imam al-Nawawi yang wafat pada hari Rabu tanggal 24 Radjab tahun $676 \mathrm{H}$ yang dimakamkan didesa Nawa, sebelah selatan kota Damsyik, yang sekarang sudah berganti nama menjadi Damaskus (Ibu Kota Negara Suriah).

Menurut al-Nawawi dalam kitabnya yang bertajuk al-Tibyan fi Adabi Hamalah al-Qur'an, dimana dalam Bab IV ia memaparkan beberapa Akhlak yang harus dimilki oleh Guru Pendidikan Agama Islam antara lain sebagai berikut: Artinya :guru seyogyanya memiliki akhlak mulia yang telah ditetapkan syara', berperilaku terpuji, memiliki sifat-sifat baik yang ditunjukan Allah seperti zuhud terhadap dunia dan mengambil seperlunya darinya, tidak mempedulikan dunia dan para pencintanya, sifat pemurah dan dermawan serta budi pekerti yang mulia, wajah yang berseri-seri tanpa melampaui batas, penyantun, sabar, bersiap wara' yang dilarang oleh syara' baik perkara syubhat maupun yang haram, khusyu' tenang, berwibawa, rendah hati dan tunduk, menghindari tertawa dan tidak banyak bergurau. Ia harus senantiasa mengerjakan amalan-amalan yang diperintahkan oleh syara' seperti membersihkan diri dari kotoran, mencukur kumis dan kuku, menyisir jenggot, menghilangkan bau busuk dan menghindari pakaian-pakaian yang kotor. Hendaklah ia menjauhi sifat dengki, 
riya' sombong, dan suka meremehkan orang lain, meskipun tingkatan orang itu dibawahnya (As-syafi'i, 2001: 29).

Pernyataan al-Nawawi tersebut sangat menarik karena Ia memberikan berbagai persyaratan yang harus dimilki oleh guru agama, Ia mencantumkan juga dalil-dalil baik dari ayat-ayat alQur'an, Hadist-Hadist Nabi atau perkataan para ulama'. Disamping itu, walaupun persyaratan akhlak yang dipaparkan al-Nawawi dikhususkan bagi guru bidang al-Qur'an, namun mempunyai pertalian yang erat dengan guru bidang keilmuan selain al-Qur'an hal ini karena al-Qur'an sendiri adalah sumber yang paling utama dalam berbagai disiplin ilmu.

\section{Biografi Imam Al-Nawawi}

\section{Nama, Asal, dan Masa Kecil al-Nawawi}

Imam Nawawi adalah seorang imam yang hafal al-Qur'an, ahli fikih, ahli hadist, pembela sunnah, penentang bid'ah, dan penghidup agama. Namun nama lengkapnya Abu Zakariya bin Syaraf bin Mar'i bin Hasan bin Husein bin Muhamad bin Jum'ah bin Hizam al-Nawawi al-Dimassiqy (Al-Nawawi, 1425: 6). Dilahirkan di Desa Nawa, wilayah Hauron, selatan kota Damsyiqy pada bulan Muharam tahun 631 H./1233 M. (As-syafi'i, 2001: 1), dahulu kakeknya yang tertua Hizam singgah Digolan, daerah Nawa, lalu tinggal disitu dan Allah Ta'ala memberikan keturunan yang banyak jumlahnya, diantaranya adalah imam ini (As-syafi'i, 2001: 2).

Sebagian orang terkemuka dinegrinya melihatnya bahwa ia memilki kepandaian dan kecerdasan. Maka ia memotivasi alNawawi untuk menghafal al-Qur'an dan menuntut ilmu. AlNawawi mulai menghafal al-Qur'an dengan dididik beberapa orang terkemuka di daerahnya. Ia sangat giat dan tekun membaca dan menghapalkan al-Qur'an. Sejak kecil ia tidak suka bermain-main dengan teman sebayanya. Sehingga pada suatu ketika, salah seorang dari gurunya, melihat anak-anak sebayanya memaksa al-Nawawi kecil main bersama mereka, namun al-Nawawi lari dari mereka sambil menangis karena paksaan mereka. Dalam keadaan yang seperti itu ia harus tetap membaca al-Qur'an hingga menghafalnya 
disaat ia mendekati usia Baligh (Shabih Muslim bi Syarah Al-Nawawi Juz I, 1401, no.1).

\section{Karya-karya}

Imam al-Nawawi telah mewariskan ilmunya melalui berbagai karangan atau kitab-kitab yang ia tulis kepada umat Islam, yang manfaatnya dapat dirasakan hingga saat ini. Fatwa-fatwa beliau juga sering menjadi rujukan ulama kontemporer dalam menetapkan hukum-hukum Islam.Diantara karya-karya beliau adalah:

1. Syarah al-Muslim berupa penjelasan dan penafsiran Nawawi terhadap hadist-hadsit nabi yang diriwayatkan oleh imam muslim

2. Riyadh al-shalihin, berisi hadist-hadist Nabi tentang adab, akhlak dan latihan-latihan penyucian jiwa untuk menuju derajat orang-orang yang shaleh.

3. Al-Azkar al-Nawawi, berisi kumpulan hadist-hadist nabi yang menyebutkan doa dan dzikir dalam kehidupan sehari-hari. Diterbitkan oleh Dar al-Malah di Damsyik.

4. Al-Tibyan Fi Adabi Hamalah Al-Qur'an menerangkan etika atau adab menjaga al-Qur'an, al-Hadist dan perkataan para ulama. (Al- Nawawi, , tt: 67)

Kitab-kitab tersebut dekenal secara luas oleh umat Islam khusunya kalangan terpelajar dan memberikan manfaat yang besar sekali untuk umat. Ini semua tidak lain karena Taufik dari Allah SWT, kemudian keikhlasannya dan kesungguhanya ia dalam bejuang.

\section{Pengertian Akhlak}

Istilah akhlak dalam bahasa Indonesia berasal dari bahasa Arab akhlaq, bentuk jamak kataKhuluk dan secara etimologis antara lain berarti budi pekerti, perangai, tingkah laku atau tabi'at (Muhammad Daud Ali, 2010: 346). Secara istilah, pengertian akhlak juga berarti sifat yang ada dalam diri seseorang untuk berbuat baik maupun berbuat buruk, bagus maupun jelek. Secara terminologi, kata akhlak dapat diartikan sebagai salah satu tingkah laku seseorang untuk 
mendapatkan dorongan atau keinginan yang timbul dari dalam diri seseorang tersebut secara sadar untuk melakukan suatu perbuatan tersebut (Abdul Qudus, 2007: 171).

Dalam Mu'jam al-Wasith dikatakan akhlak adalah sifat yang tertanam dalam jiwa, yang dengannya lahirlah macam-macam perbuatan, baik atau buruk tanpa membutuhkan pemikiran dan pertimbangan. Sedangkan menurut Prof. Dr. Ahmad Amin mengatakan bahwa akhlak ialah kebiasaan kehendak, hal ini berarti bahwa apabila kehendak itu dibiasakan ia akan menjadi sosok akhlak (Abdul Qudus, 2007: 171-172).

Imam Ghazali mengatakan: Akhlak adalah sifat yang tertanam dalam jiwa yang menimbulkan perbuatan-perbuatan dengan mudah tanpa memerlukan pemikiran dan pertimbangan. Sedangkan Abdullah Daraz mengemukakan bahwa akhlak adalah suatu kekuatan dalam kehendak yang mantap yang membawa kecenderungan kepada pemilihan pada pihak yang benar (akhlak yang baik) atau pihak yang jahat (akhlak yang buruk) (Abdul Qudus, 2007: 171-172).

Sedangkan Akhlak Menurut Muhammad bin Ali Asy Syariif Al Jurjani: Akhlak adalah sesuatu sifat (baik atau buruk) yang tertanam kuat dalam diri yang darinya terlahir perbuatan-perbuatan dengan mudah dan ringan tanpa perlu berpikir dan merenung. DanAkhlak Menurut Ahmad bin Mushthafa: Akhlak adalah ilmu yang darinya dapat diketahui jenis-jenis keutamaan dan keutamaan itu adalah terwujudnya keseimbangan antara tiga kekuatan; kekuatan berpikir, kekuatan marah, dan kekuatan syahwat. Akhlak Menurut Ibnu Maskawaih: Akhlak adalah sifat yang tertanam dalam jiwa yang mendorongnya untuk melakukan perbuatan tanpa memerlukan pemikiran dan pertimbangan (http:/ / www.pengertianahli.com/2013/10/pengertian-akhlakmenurut-para-ahli.html). A-Qurthuby menekankan bahwa akhlak merupakan bagian dari keberadaan manusia, sehingga al-khuluq tidak terpisahkan dari kata al-khilqah yang merupakan keadaan fitrah yang senantiasa dapat mempengaruhi segala perbuatan manusia. 
Disamping istilah akhlak kita juga mengenal etika dan moral, ketiga istilah itu sama-sama menentukan nilai baik dan buruk dari sikap dan perbuatan manusia. Akhlak standarnya adalah al-Qur'an dan Sunnah sedangkan etika standarnya pertimbangan akal pikiran dan moral standarnya adat kebiasaan yang umum berlaku dimasyarakat (Didiek Ahmad, 2011: 217).

Dari beberapa pengertian tersebut diatas dapat disimpulkan bahwa Akhlak adalah tabiat atau sifat seseorang, yakni keadaan jiwa yang telah terlatih, sehingga dalam jiwa tersebut benar-benar telah melekat dalam sifat-sifat yang melahirkan perbuatan-perbuatan dengan mudah dan spontan, tanpa dipikirkan dan diulang-ulang terlebih dahulu.

Hal ini berarti bahwa perbuatan tersebut telah dilakukan dengan tidak disengaja atau tidak dikehendaki, hanya saja yang demikian itu dilakukan berulang-ulang sehingga menjadi kebiasaan, maka perbuatan itu muncul dengan mudah tanpa difikir dan dipertimbangkan lagi (Didiek Ahmad, 2011: 219).

\section{Akhlak Guru Agama Islam}

Dalam buku adab Al-Alim Wa Muta'alim yang dikarang oleh K.H. M.Hasyim Asy'ari Tebu Ireng Jombang menguraikan bahwa lima belas akhlak seorang guru agama yaitu:

1. Agar selalu istiqomah dalam muraqobah kepada allah SWT.

2. Senantiasa berlaku khauf dalam segala ucapan dan tindakan.

3. Senantiasa bersikap tenang

4. Senantiasa bersikap wara'

5. Selalu bersikap tawadhu'

6. Selalu bersikap khusyu' kepada Allah SW'T

7. Menjadikan Allah sebagai tempat meminta pertolongan dalam segala keadaan

8. Tidak menjadikan ilmunya sebagai tangga untuk mencapai keuntungan duniawi

9. Tidak deskriminatif terhadap peserta didik

10. Bersikap zuhud terhadap urusan dunia sebatas apa yang ia butuhkan 
11. Menjauhkan diri dari tempat-tempat kotor dan maksiat

12. Agar selalu menjaga siar-siar Islam dan zahir-zahir hukum, seperti shalat berjamaah di masjid

13. Menegakan sunah-sunah dan menghafus segala hal yang mengandung bid'ah

14. Membiasakan melakukan hal sunah yang bersifat syaria't

15. Bergaul dengan akhlak yang baik (Hully Mukhtar, 2012: 92-93).

Selanjutnya KH. Hasyim As'Ari menawarkan gagasan tentang etika atau adab-adab guru ketika mengajar sebagaimana berikut:

"Mensucikan diri dari hadas dan kotoran; berpakaian yang sopan dan rapi serta usahakan berabau wangi; berniatlah beribadah ketika dalam mengajarkan ilmu kepada peserta didik ; sampaikanlah hal-hal yang diajarkan oleh Allah; biasakanlah membaca untuk menambah ilmu pengetahuan; berilah salam ketika masuk ke dalam kelas; sebelum mengajr mulailah terlabih dahulu dengan berdoa untuk para ahli ilmu yang telah lama maninggalkan kita; berpenampilan yang kalem dan jauhi hal-hal yang tidak pantas dipandang mata; menjauhkan diri dari banyak bergurau dan banyak tertawa; jangan sekali-kali mengajar dalam kondisi lapar, marah, mengantuk, dan sebagainya; pada waktu mengajar hendaklah mengambil duduk yang strategis; usahakan tampil dengan sikap ramah, lemah lembut, jelas dalam betutut, tegas, lugas, dan tidak sombong; dalam mengajar hendaklah mendahulukan materi-materi yang penting dan sisesuikan dengan profesi yang dimiliki; jangan sekali-sekali mengerjakan hal-hal yang bersifat syubhat dan bisa membinasakan; perhatikan masing-masing kemampuan peseerta didik dalam mengajar dan tidak terlalu lama, serta menciptakan ketenangan dalam ruangan belajat; menasihati dan menegur dengan baik bila mterdapat peserta didik yang bandel; bersikaplah terbuka terhadap berbagai macam persoalan yang ditemukan; berilah kesempatan kepada peserta didik yang datangnya ketinggalan dan ulangilah penjelasan agar tahu apa yang dimaksud, dan bila sudah selesai, berilah kesempatan kepada peserta didik untuk menanyakan hal-hal yang kurang jelas atau belum dipahami". (http:/ / www.fimadani.com/pendidikan-adab-kh-hasyimasyari/)

Seorang guru harus berniat mendidik dan menyebarkan ilmu pengetahuan serta menghidupkan syariat Islam. Menghindari ketidak ikhlasan dan mengejar keduniawian; hendaknya selalu melakukan intrsopeksi diri; menggunakan metode yang mudah 
dipahami oleh para peserta didik; membangkitkan antusias peserta didik dengan memotivasinya; memberikan latihan-latihan yang bersifat membantu; selalu memperhatikan kemampuan peserta didik; tidak terlalu mengorbitkan salah seorang peserta didik dan menafikan yang lainnya; mengarahkan minat peserta didik; bersikap terbuka dan lapang dada terhadap peserta didik; membantu memecahkan masalah dan kesulitan para peserta didik; bila terdapat pseta didik yang berhalangan hendaknya mencari hal ikhwal kepada teman-temannya; tunjukkan sikap arif dan penyayang kepada peserta didik; dan selalulah rendah hati, tawadhu". (Hully Mukhtar, 2012: 100)

Keberhasilan peserta didik di dalam kelas tentu bukan saja ditentukan oleh peserta didik itu sendiri namun juga keberhasilan peserta didik sangat ditentukan oleh Fasilitator dalam hal ini seorang guru yang selalu berusaha membimbing dan menjadi tauladan bagi peserta didiknya. Menjadi seorang guru bukan hanya perkara mengajarkan atau menyampaikan materi namun terlebih penting seorang guru menjadi orang yang paling bertanggung jawab atas peserta didiknya. Pendidik berarti juga orang dewasa yang bertanggung jawab memberi pertolongan pada peserta didiknya dalam perkembangan jasmani dan rohaninya, agar mencapai tingkat kedewasaan, mampu berdiri sendiri dan memenuhi tingkat kedewasaannya, mampu mandiri dalam memenuhi tugasnya sebagai hamba Allah dan Khalifah. Dan mampu melaksanakan tugas sebagai makhluk sosial dan sebagai makhluk individu yang mandiri (Mujib, dan Mudzakkir, 2008: 87). Dalam paradigma Jawa, pendidik diidentikkan dengan guru, yang mempunyai makna "Digugu dan ditiru" artinya mereka yang selalu dicontoh dan dipanuti.

Dalam Kamus Besar Bahasa Indonesia guru adalah seorang yang pekerjaannya (mata pencahariannya, profesinya) mengajar. Dalam bahasa Arab disebut Mu'allimdan dalam bahasa Inggris disebut Teacher. Itu semua memiliki arti yang sederhana yakni "A Person Occupation is Teaching Other" artinya guru ialah seorang yang pekerjaannya mengajar orang lain. 
Menurut Ngalim Purwanto bahwa guru ialah orang yang pernah memberikan suatu ilmu atau kepandaian kepada seseorang atau sekelompok orang (Purwanto, 2003: 33). Selanjutnya menurut Hadari Nawawi bahwa pengertian guru dapat dilihat dari dua sisi yaitu "Pertama secara sempit, guru adalah ia yang berkewajiban mewujudkan program kelas, yakni orang yang kerjanya mengajar dan memberikan pelajaran di kelas. Sedangkan secara luas diartikan guru adalah orang yang bekerja dalam bidang pendidikan dan pengajaran yang ikut bertanggung jawab dalam membantu dalam mencapai kedewasaan masing-masing" (http:/ / fajarnoverdi.blogspot.com/2013/03/akhlak-guru-terhadapmurid-dan-murid.html).

Pengertian-pengertian diatas menurut Muhibbin Syah masih bersifat umum, dan oleh karenanya dapat mengundang bermacammacam interpretasi dan bahkan juga konotasi (arti lain). Pertama adalah kata "seorang (A Person) bisa mengacu pada siapa saja asal pekerjaan sehari-harinya (profesinya) mengajar. Dalam hal ini berarti bukan hanya dia yang sehari-harinya mengajar disekolah yang dapat disebut guru, melainkan juga dia-dia yang lainnya yang berprofesi (berposisi) sebsagai Kyai di pesantren, pendeta di gereja, instruktur di balai pendidikan dan pelatihan, kedua adalah kata "mengajar" dapat pula ditafsirkan bermacam-macam.

\section{Akhlak guru pendidikan agama islam menurut al-Nawawi dalam kitab Al-Tibyan Fi Adabi Hamalah Al-Qur'an}

Guru merupakan salah satu tema yang banyak dipakai untuk menyebut seseorang yang dijadikan panutan. Penggunaan istilah ini tidak hanya dipakai dalam dunia pendidikan, tetapi hampir semua aktivitas yang memerlukan seorang pelatih, pembimbing dan sejenisnya. Sosok guru menyiratkan pengaruh yang luar biasa terhadap semua peserta didiknya sehingga baik tidaknya peserta didik sangat ditentukan oleh guru.

Hully Mukhtar mengatakan "Guru adalah orang yang memikul tanggungjawab untuk membimbing diamana dia tidak hanya bertanggungjawab menyampaikan materi pelajaran kepada peserta 
didik tetapi juga bertanggungjawab membentuk keperibadian (moral/akhlak) peserta didik bernilai tinggi. Lebih jauh lagi dijelaskan bahwa guru adalah orang dewasa yang bertanggungjawab memberikan bimbingan kepada peserta didik dalam perkembangan jasmani dan rohaninya agar mencapai kedewasaan, mampu melaksanakan tugasnya sebagai makhluk Allah,makhluk sosial, dan sebagai individu yang berdiri sendiri” (Hully Mukhtar, 2012: 70-71).

Guru memiliki arti dan peranan yang sangat besar. Hal ini disebabkan ia memilki tanggung jawab dan menentukan arah pendidikan. Oleh karena itu Islam sangat menghormati dan menghargai kedudukan guru sebagai orang yang berilmu pengetahuan.Keperibadian guru dalam sejarah peradaban Islam seakan menjadi kunci dalam pembentukan akhlak dan perilaku peserta didik. Keperibadian yang mantap, stabil, dan dewasa harus dimilki oleh guru agar dapat melaksanakan tugasnya dengan baik. Oleh sebab itu pula Imam al-Nawawi dalam kitab al-Tibyan Fi Adabi Hamalah al-Qur'an menyarankan agar guru dapat melaksanakan tugasnya dengan baik supaya memilki keperibadian akhlak yang baik pula.

Pada bab IV dalam kitab Al-Tibyan Fi Adabi Hamalah AlQurán ia menyebutkan serangkaian keperibadian (Akhlak/Etika) yang hendak dimiliki oleh guru, diantaranya:

Pertama, Guru hendaknya bertujuan mengharapkan keridhaan Allah dalam melaksanakan tugasnya, sebagaiman yang disampaikan oleh al-Nawawi:Hal pertama yang hendak dilakukan oleh guru PAI dan peserta didik adalah mengharapkan ridha Allah Ta'la. Banyak dalil yang menganjurkan bahwa keikhlasan menjadi kunci diterimanya amal, Allah Ta’la berfirman:

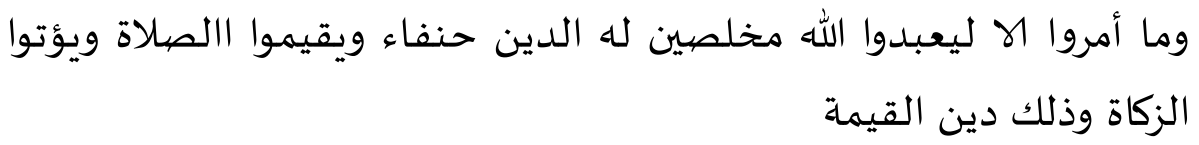

Artinya: padahal mereka tidak disuruh kecuali supaya menyembah Allah dengan memurnikan ketaatan kepadaNya dalam menjalankan agama yang lurus, dan supaya mereka mendirikan shalat dan menunaikan zakat yang demikian itulah agama yang lurus.(Q.S.al-Bayyinnat: 5) 
Al-uztaz Abu al-Qasim al-Quraisy berkata: Artinya: Ikhlas ialah taat kepada Allah saja dengan tujuan mendekatkan diri kepada Allah Swt tanpa ada tujuan yang lain, seperti berpura-pura kepada makhluk atau menunjukan perbuatan baik kepada orang banyak, mengharapkan kecintaan dan pujian dari mereka atau suatu makna selain mendekatkan diri kepada Allah."ia juga berkata : "boleh dikatakan ikhlas itu adalah membersihkan perbuatan dari perhatian makhluk (Al- Nawawi, tt: 24).

Menurut Hudzaifah al-Mar'asyri yang dikutip oleh Al Nawawi "ikhlas adalah kesamaan antara perbuatan-prbuatan hamba pada lahir dan batinnya. Fudail bin Iyadh mengatakan bahwa meninggalkan amal demi banyak orang adalah Riya' dan beramal demi orang banyak adalah syirik, sedangkan ikhlas adalah bila Allah membebaskan seseorang dari keduanya" (Al- Nawawi, , tt: 24-25). Jadi lawan dari kata Riya' yaitu suka memamerkan amal ibadahnya baik lahir maupun batin. Minsalnya seorang melaksanakan shalat berjamaah dengan tujuan mendapatkan pujian dari orang lain atau beramal shadaqah agar dilihat dan dipuji orang lain.

Al-Harits al-Mhaisiby r.a. berkata, Artinya: orang yang benar itu tidak peduli meskipun ia keluar dari segala apa yang ditetapkan dalam hati makhluk terhadapnya mengenai kebaikan hatinya. Dan ia tidak suka orang-orang mengetahui kebaikan perbuatannya sedikitpun dan tidak benci apabila orang-oranag mengetahui perbuatannya yang buruk, karena kebenciannya akan hal itu adalah suatu bukti bahwa ia menyukai sanjungan atau pujian dari mereka. Yang demikian itu bukan termaksuk akhlak orang-orang yang benar.

Kedua, dalam kitabal-Tibyan Fi Adabi Hamalah al-Qurán, alNawawi mengatakan: "Seyogyanya guru tidak bertujuan dengan ilmunya untuk mencapai suatu tujuan dari berbagai kepentingan duniawi, baik berupa harta benda, kepemimpinan kedudukan, keunggulan atas saingannya, pujian dihadapan manusia, dan mengarahkan perhatian masyarakat kepadanya serta hal-hal semisal itu." (Al- Nawawi, tt: 26)

Allah Taála Berfirman: 


\section{ومن كان يريد حرث الدنيا نؤتاه منها وماله في الاخرة من نصيب[ الشور . ]}

Artinya: “.....barang siapa yang menghendaki keuntungan didunia, kami berikan kepadanya sebagian dari keuntungan dunia dan tidak ada baginya suatu bagianpun diakhirat.” (QS. Al-Syura'; 20)

Ketiga, hendaknya guru bersikap waspada untuk tidak bermaksud memaksakan banyak orang yang belajar dan datang kepadanya serta tidak membenci peserta didiknya yang belajar kepada orang lain yang dapat memberikan manfaat kepada mereka. Al-Nawawi berkata: 'Guru hendaknya benar-benar waspada untuk tidak bermaksud memaksakan banyaknya orang yang belajar dan datang kepadanya serta tidak membenci peserta didiknya yang belajar kepada orang lain yang dapat memberikan manfaat kepada mereka. Ini adalah musibah yang menimpa sebagian guru yang bodoh dan menunjukan bahwa niatnya buruk dan batinnya rusak. Bahkan itu adalah bukti yang jelas bahwa ia tidak menginginkan keridhaan Allah yang Maha Mulia. Karena itu jika ia menginginkan keridhaan Allah dengan pengajarannya, tentulah ia tidak membenci hal itu, tetapi ia katakan pada dirinya: "ak menginginkan ketaatan dengan mengajarnya dan sungguh ak telah berhasil. Dengan belajar pada orang lain Ia ingin menambah ilmu, maka ia tidak bisa dipersalahkan.

Telah diriwayatkan dalam musnad imam yang diakui hafalannya dan kepemimpinannya, Abu Muhamad al-Darimi r.a. dari Ali bin Abi Thalib r.a. ia berkata: "Hai orang-orang yang berilmu! Amalkanlah ilmumu, karena orang alim itu ialah orang yang mengamalkan apa yang diamalkannya. Akan muncul orangorang yang mempunyai ilmu tetapi ilmunya tidak melampaui tenggorokan mereka, dan perbuatan mereka bertentangan dengan ilmu mereka serta batin mereka bertentangan dengan lahirnya. Mereka duduk-duduk di majelis-majelis dan sebagian mereka membanggakan diri kepada sebagian yang lain hingga ada orang yang marah kepada teman duduknya karena belajar dengan orang lain dan meninggalkannya. Aktivitas amal-amal mereka di majelismajelis itu tidak akan sampai kepada Allah (Al- Nawawi, tt: 28). 
Keempat, guru hendaknya memiliki akhlak yang baik sebagaimana ditetapkan oleh syara' berperilaku terpuji dan memilki sifat-sifat yang baik yang dianjurkan oleh Allah. Sebagaimana di ungkapkan oleh al-Nawawi yang artinya: guru seyogyanya memiliki akhlak mulia yang telah ditetapkan syara', berperilaku terpuji, memiliki sifat-sifat baik yang ditunjukan Allah seperti zuhud terhadap dunia dan mengambil seperlunya darinya, tidak mempedulikan dunia dan para pencintanya, sifat pemurah dan dermawan serta budi pekerti yang mulia, wajah yang berseri-seri tanpa melampaui batas, penyantun, sabar, bersiapkap wara' yang dilarang oleh syara' baik perkara syubhat maupun yang haram, khusyu' tenang, berwibawa, rendah hati dan tunduk, menghindari tertawa dan tidak banyak bergurau. Ia harus senantiasa mengerjakan amalan-amalan yang diperintahkan oleh syara' seperti membersihkan diri dari kotoran, mencukur kumis dan kuku, menyisir jenggot, menghilangkan bau busuk dan menghindari pakaian-pakaian yang kotor. Hendaklah ia menjauhi sifat dengki, riya' sombong, dan suka meremehkan orang lain, meskipun tingkatan orang itu dibawahnya. (Al- Nawawi, tt: 29)

Kelima, guru hendaknya bersikap lemah lembut kepada peserta didiknya. Menyambut dengan baik terhadap orang yang ingin belajar kepadanya serta memperlakukan dengan baik sesuai dengan keadaannya. Sebagaimana diungkapkan oleh al-Nawawi: "Seyogyanya guru bersikap lemah lembut terhadap orang yang belajar kepadanya, menyambutnya dengan baik serta memperlakukannya secara baik pula sesuai dengan keadaannya." (Al- Nawawi, tt: 30)

Keenam, guru senantiasa memberikan nasehat atau petuah kepada para peserta didiknya. Al-Nawawi berkata: "Guru seyogyanya mencurahkan nasehat kepada para peserta didiknya, karena Rasullalllah Saw. Bersabda: "Agama itu nasehat, bagi Allah, kitabNya, RasulNya, para pemimpin muslim dan orang awam diantara mereka. (HR.Muslim dan ibnu Majah).

Termaksud nasehat dari Allah dan KitabNya ialah menghormati pembaca al-Qurán dan pelajarnya, membimbingnya kepada 
kebaikan, bersikap lemah lembut dan memotivasi dalam belajar serta membujuk hati peserta didik di samping bersikap lapang dan lunak dalam peroses pembelajaran.

Al-Nawawi mengungkapkan sikap terhadap peserta didik: "Guru hendaknya menyayangi peserta didiknya dan memperhatikan kemaslahatan-kemaslahatannya sebagaimana perhatiannya terhadap kemaslahatan diri dan anaknya sendiri. (oleh karena itu) guru hendaknya memperlakukan peserta didiknyaseperti anak sendiri yang harus disayangi dan diperhatikan kebaikannya, sabar menghadapi gangguan dan kelakuannya yang buruk, serta bersikapa pemaaf terhadap kesalahan mereka, karena sesungguhnya manusia cenderung berbuat salah, apalagi bila masih kecil."

Telah diriwayatkan dalam Sahihain dan Rasullalllah Saw, beliau Bersabda artinya: "Seseorang diantara kalian masih belum dikatakan beriman sebelum ia mencintai saudaranya sebagaimana ia mencintai dirinya sendiri."

Ketujuh, guru tidak boleh menyombongkan diri kepada para peserta didik. Sebagaimana dikatakan al-Nawawi "Guru seyogyanya tidak menyombongkan diri terhadap para pelajar. Ia (hendaknya) bersikap lunak dan tawadhu' (merendahkan diri) terhadap mereka" (Al- Nawawi, tt: 32).

Telah Diriwayatkan dari Nabi saw. Bahwa beliau bersabda: Artinya:Bersikaplah lunak kepada orang yang kalian ajaridan guru yang mengajari kamu.

Kedelapan, guru hendaknya mendidik peserta didiknya secara berangsur-angsur dengan adab-adab yang luhur dan perilaku yang baik. Dalam kitab al-Tibyan Fi Adabi Hamalah Al-Qur'an AlNawawi memaparkan metode mengajar sebagai berikut: "Guru hendaknya mendidik peserta didiknya secara berangsur-angsur dengan adab-adab yang luhur dan perilaku yang baik, melatihnya dengan hal-hal yang kecil terpuji, serta membiasakannya agar memelihara diri dari segala perkara lahir dan batin, memotivasinya denga baik dan dengan perkataan ataupun dengan perbuatannya agar tetap bersikap ikhlas, jujur dan memperbagus niat serta Bermuraqobah( merasa selalu di awasi) oleh allah dalam segala 
keadaan. Kemudian memberitahukan kepada para peserta didiknya bahwa dengan sebab itu terbukalah cahaya Ma'rifatdiatasnya, dadanya menjadi lapang, memancar dari hatinya sumber-sumber hikmah dan pengetahuan. Allah akan memberikannya berkah pada ilmu amalnya serta memberikan petunjuk pada setiap perbuatannya." (Al- Nawawi, tt: 33)

Kesembilan, guru hendaknya lebih mementingkan pengajaran kepada peserta didiknya melabihi kemaslahatan dirinya yang bersifat duniawi dan bukan kebutuhan ,primer yang sangat mendesak. Guru hendaknya menghindari diri dari sifat dengki terhadap peserta didiknya. Dalam kitab Al-Tibyan Fi Adabi Hamalah Al-Qur'an diungkapkan materi pembelajaran sebagai berikut: "Dianjurkan bagi guru untuk meningkatkan pengajaran mereka dengan melebihkannya diatas kemaslahatan dirinya bersifat duniawi yang bukan kebutuhan mendesak darurat. Hendaklah ia mengosongkan hatinya dari segala hal yang menyibukannya disaat duduk untuk mengajari mereka. Hendaklah ia berusaha keras untuk memberikan pemahaman kepada mereka dan memberi masingmasing dari mereka bagian pelajaran yang layak. Maka janganlah ia memberi mereka banyak pelajaran kepada peserta didik yang tidak bisa menerima secara menyeluruh dan jangan meringkas bagi mereka yang menerima tambahan. Guru hendaknya menyuruh para peserta didknya mengulang-ulang hafalannya dan memuji siapasiapa yang menonjol kecerdasannya selama tidak dikahwatirkan fitnah sebab bangga atau lainnya. Siapa yang kurang perhatiannya, bolehlah ia menegurnya dengan lemah lembut selama ia tidak takut peserta didik itu akan lari. Janganlah dengki kepada salah seseorang peserta didknya karena kepandaian yang menonjol dari peserta didiknya dan jangan menganggap banyak kepadanya nikmat yang diberikan allah kepadanya. Karena sikap dengki terhadap orang lain sangat diharamkan terlebih terhadap pesert didik yang berkedudukan seperti anak." (Al- Nawawi, tt: 34)

Kesepuluh, jika peserta didiknya banyak jumlahnya, hendaknya guru melakukan pengajarannya pada peserta didiknya, lalu yang berikutnya. Apabila yang pertama rela gurunya mendahulukan yang 
lain, maka boleh mendahulukannya, al-Nawawi berkata supaya menerapkan pembelajaran sebagai berikut: Dalam pengajarannya apabila peserta didiknya banyak, maka hendaknya didahulukan yang pertama lalu yang berikutnya, jika yang pertama rela gurunya mendahulukan yang lain, maka boleh mendahulukannya (AlNawawi, tt: 35). Guru seyogyanya menampakan kegembiraan dan wajah yang berseri-seri, memeriksa keadaan mereka dan menanyakan siapa dari mereka yang absen.

Berdasarkan paparan data diatas maka peneliti dengan ini mengidentifikasi bahwa guru PAI hendaknya berakhlak sbb:

a) Hal pertama yang hendak dilakukan oleh guru al-Qurán dan peserta didik adalah mengharapkan ridha Allah Ta'la

b) "Seyogyanya guru tidak bertujuan dengan ilmunya untuk mencapai suatu tujuan dari berbagai kepentingan duniawi, baik berupa harta benda, kepemimpinan kedudukan, keunggulan atas saingannya, pujian dihadapan manusia, dan mengarahkan perhatian masyarakat kepadanya serta hal-hal semisal itu."

c) Hendaknya guru bersikap waspada untuk tidak bermaksud memaksakan banyak orang yang belajar dan datang kepadanya serta tidak membenci peserta didiknya yang belajar kepada orang lain yang dapat memberikan manfaat kepada mereka

d) Guru hendaknya memiliki akhlak yang baik sebagaimana ditetapkan oleh syara' berperilaku terpuji dan memilki sifatsifat yang baik yang dianjurkan oleh Allah.

e) Guru hendaknya bersikap lemah lembut kepada peserta didiknya. Menyambut dengan baik terhadap orang yang ingin belajar kepadanya serta memperlakukan dengan baik sesuai dengan keadaannya.

f) Guru senantiasa memberikan nasehat atau petuah kepada para muridnya

g) Guru tidak boleh menyombongkan diri kepada para pelajar. 
h) Guru hendaknya mendidik peserta didiknya secara berangsur-angsur dengan adab-adab yang luhur dan perilaku yang baik.

i) Guru hendaknya lebih mementingkan pengajaran kepada peserta didiknya melabihi kemaslahatan dirinya yang bersifat duniawi dan bukan kebutuhan ,primer yang sangat mendesak

j) Jika peserta didiknya banyak jumlahnya, hendaknya guru melakukan pengajarannya pada peserta didiknya, lalu yang berikutnya

k) Guru harus adil tidak boleh pilih kasihTermasuk sikap guru yang perlu ditekankan dan diperhatikan adalah menjaga setiap anggota tubuhnya dari bermain-main di kala mengajar.

\section{Catatan Akhir}

Akhlak guru agama pendidikan Islam dalam pandangan Imam al-Nawawi mengacu pada beberapa hal, yakni:

Keperibadian yang mantap, stabil dan dewasa. Menurut alNawawi guru harus bersikap ikhlas hanya mencari keridhaan Allah dalam melaksanakan tugasnya, tidak mencintai pangkat dan kemewahan dunia, serta tidak memilki sifat dengki.

Disiplin, arif dan berwibawa. Guru hendaknya lebih memperhatikan kemaslahatan peserta didiknya diatas kemaslahatan dirinya sendiri, memilki kesabaran dalam menghadapi beragam watak, peserta didik, pemaaf. Selain itu guru hendaknya mendidik dan melatih peserta didiknya secara bertahap denga perilaku yang terpuji, mengosongkan hati dari segala kesibukan lain disaat duduk mengajar, berikap bijaksana terhadap siapa saja yang ingin belajar padanya, menjaga kewibawaan ilmu dan tidak merendahkan ilmu,

Berakhlak mulia dan menjadi teladan bagi peserta didik. Guru hendaknya memilki akhlak mullia, baik akhlak dengan Allah maupun akhlak dengan sesama manusia serta menjaga adab-adab lahir dan batin agar dapat diteladani oleh peserta didiknya. 


\section{Daftar Pustaka}

Abdul Mujib, Mudzakkir Jusuf. Ilmu Pendidikan Islam. Jakarta: Kencana, 2008.

Abdul Qudus. Islam Multidimensi. Jogjakarta: Longge perintika.2007

Abi zakariya Yahya bin Syarafudin An-Nawawi As-Syafi'i. al-Tibyan fi Adabi Hamalah al-Qur'an, Jakarta: Pustaka Asmani, 2001.

Al- Nawawi, Al-Ad₹karrun Nawawi. Maktabah Walmutbaah Putra Semarang, tt.

Al-Nawawi, Dalillul Falibin Juгu' Awal, Baerut Labnan :1426-1425.

Depag RI, al-Qur"an dan Terjamah

Didiek Ahmad. Pengantar Studi Islam. Jakarta: Raja Grafindo Persada: 2011.

http:/ /al-badar.net/pengertian-dan-pendapat-ulama-tentang-

akhlaq/, diakses tanggal 10 oktober, 21.38 wita

http:/ / fajarnoverdi.blogspot.com/2013/03/akhlak-guru-terhadap-

murid-dan-murid.html, diakses 13 oktober, 19.45 wita.

http:/ /www.fimadani.com/pendidikan-adab-kh-hasyim-asyari/

diakses 11 oktober, 18.34 wita

http:/ /www.pengertianahli.com/2013/10/pengertian-akhlak-

menurut-para-ahli.html diakses tanggal 9 oktober, 20.30 wita

Hully Mukhtar. profesi keguruanMataram : Alam Tara Institute,2012

Muhammad Daud Ali. Pendidikan Agama Islam, Jakarta: PT. Raja

Grafindo Persada. 2010

Ngalim Purwanto. Filsapat Ilmu Pendidikan, Jakarta: Putra Sejati Raya, 2003

Shabih Muslim Bi Syarah Al-Nawawi Juz I. Daar al-Fikr 1401 H/1981 M. 